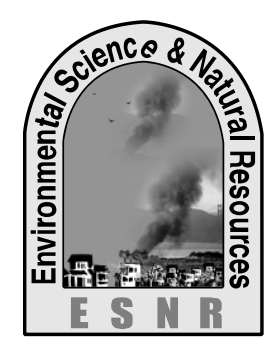

\title{
Reducing the Volume of Garbage and Production of Biogas through Anaerobic Decomposition
}

\author{
M. H. Rahman ${ }^{1}$, S. H. Mia ${ }^{1}$, A. Nessa ${ }^{2 *}$, M. A. Badhan ${ }^{3}$ and M. A. Islam ${ }^{3}$ \\ Department of Environmental Science and Resource Management \\ ${ }^{1}$ Mawlana Bhashani Science and Technology University, Tangail-1902 \\ ${ }^{2}$ Department of Soil, Water and Environment, University of Dhaka, Dhaka-1000 \\ ${ }^{2}$ Department of Environmental Science, Bangladesh Agricultural University, Mymensingh \\ *Corresponding author: ashrafunrita@gmail.com
}

\begin{abstract}
Biogas is one of the most eco-friendly alternative renewable energy sources, to meet future energy requirement. In order to carry out this research, two experiments were set up taking cow dung, cow dung with wasted flour and cultured Bacteria with waste flour. In Experiment 1, only cow dung was used in build biogas plant and decomposed periodically for 28 days. After that cow dung slurry (as inoculum) with waste flour were decomposed for 28 days. In Experiment 2, same waste flour with cultured anaerobic bacterial colony (as inoculum) was used as the feed stocks and the experiment was completed in 28 days. Result of the Study revealed that production of biogas was higher and consuming less time when cultured bacterial colony was used as inoculum with feed stock, compared to that of cow dung. In this experiment, garbage is decomposed with approximately all type of anaerobic bacteria. If methanogens, facultative anaerobes and other bacteria which are responsible for anaerobic digestion and biogas formation, are separately cultured and these garbage's are separately decomposed with this bacteria. Anaerobic decomposition has a number of environmental benefits including production of 'green' energy and natural fertilizers. The process of converting organic feed stock into biogas can serve as a substitute for fossil fuels and artificial fertilizers, reducing the amount of greenhouse gases released into the atmosphere.
\end{abstract}

Key words: Anaerobic bacteria, Biogas, Eco-friendly, Garbage

\section{Introduction}

Fossil fuels (like coal, gas and petrol etc.) are the largest emitters of greenhouse gases such as carbon dioxide and methane which are negatively impacting the ozone layer, which is essential for the survival of all species. Further, these greenhouse gases are also responsible for global warming and climate change. With the modernization of our society, our demands for energy are increasing gradually. In today's energy demanding life style, we need to explore and exploit new sources of energy which should be renewable as well as ecofriendly (Ali, 1995; UNDP, 1995). Biogas, biochar (by products of anaerobic digestion) can be used as ecofriend biomass. Bangladesh is one of the most densely populated countries with limited land area and natural resources (about $0.06 \mathrm{ha} /$ person). Because of increased population pressure, huge amount of natural resources are being used every day and the quality of the environment is deteriorating directly and indirectly through various anthropogenic as well as natural activities. Nevertheless, this environmental deterioration has ultimately posed a threat to human civilization on global arena (Kabir and Mahmud, 2009). Biogas is a renewable source of energy, is being used as fuel for cooking, lighting, running vehicles and generators etc. Other natural resources like oil, gas etc. are limited and will be exhausted in course of time. That is why; the developed countries consider their natural resources as very precious and are cautious about extracting those. In Bangladesh neither the decision-makers nor the experts pay due importance on proper extraction and use of natural resources. With the present rate of consumption, natural energy resources

\section{Materials and Methods}

In order to carry out the research, the whole study was divided into three major phases based upon the like gas may be exhausted shortly and this is high time to derive policy and practice for exploration and use of alternative renewable sources if we want to meet energy crisis in near future. Biogas has been found to be a proven renewable energy option (Gareth and Judith, 2003). Biogas produces more heat than kerosene, fuel wood, charcoal and dung-cakes. When biogas is used in suitable designed burners, it gives a clean, smokeless, blue flame, which is ideal for cooking. If biogas is used in specially designed lamp it gives a light similar to the kerosene pressure lamps. Biogas can be used for other purposes such as electricity generation, refrigeration, space heating and running engines but higher amount gas will be required for these purposes. Family size biogas plant is appropriate only for the domestic use such as cooking and lighting (Rahman, 1996). Bangladesh is in a favorable condition in respect of the climatic conditions and availability of the raw materials for biogas production. The optimum mesophilic range for biogas generation is $25^{0} \mathrm{C}-37^{\circ} \mathrm{C}$. Bangladesh is blessed with this range of temperature almost throughout the year. In Bangladesh, there are about 22 million of cattle which excrete about 220 million $\mathrm{kg}$ of dung per day. This can produce an average $2.97 \times 10^{9} \mathrm{~m}^{3}$ of biogas/year which is equivalent to $1.52 \times 10^{6}$ tons of kerosene. Besides this, a considerable amount of gas and organic fertilizer can be obtained from poultry droppings, human excreta, garbage, water hyacinth etc. (Monique et al., 1986). The main objectives of the study were; to reduce the volume of different types of biodegradable wastes, to produce the more amount of biogas and to learn about methanogens.

activities carried out. The general methodology followed during the study has been illustrated in the following diagram: 


\begin{tabular}{|l|l|l|}
\hline $\begin{array}{l}\text { Preliminary Phase: Desk } \\
\text { Study and Mobilization }\end{array}$ & $\begin{array}{l}\text { Investigation and Data } \\
\text { Collection Phase: Built a } \\
\text { Biogas Plant, Bacteria } \\
\text { Culture }\end{array}$
\end{tabular}

Fig. 1. Methodology Adopted during the Study

\section{Results and Discussion}

\section{Analyzing biogas production and required time}

In the research for analyzing biogas production, three characteristics of waste were used. These were cow dung (waste sample-1), waste flour with cow dung (waste sample-2) and cultured bacteria with waste flour (waste sample-3). The gas production rates of each waste were sample were table 1 and table 2 . In each waste sample the experiments were continued for 28 days.

Quantity of biogas on daily basis from cow dung and waste flour with cow dung

Table 1 illustrates the cumulative quantity of biogas production from cow dung (sample-1) and waste flour with cow dung (sample-2) within 28 days. It has been shown from Table 3 shows that the production of biogas followed an increase trend with time period, for example when cow dung slurry was used as waste material. The biogas production was $0.1 \mathrm{~L}$ during at day 5 and it was gradually increased until day 28 and produced $2 \mathrm{~L}$ biogas at the end of the experiment. At the same time, this experiment revealed that as waste feed stock while waste flour with cow dung was used for gas production. The biogas production was $1.6 \mathrm{~L}$ during at day 5 and it was gradually increased until day 28 and produced $21.3 \mathrm{~L}$ biogas at the end of the experiment.

Table 1. Biogas produced daily when 10 liter slurry is decomposed from cow dung and waste flour with cow dung

\begin{tabular}{|c|c|c|c|}
\hline \multirow[b]{2}{*}{ Day } & \multicolumn{3}{|c|}{ Daily volume of gas produced from each Feedstock's (L) } \\
\hline & $\begin{array}{l}\text { Cumulative amount of } \\
\text { gas from Cow dung }\end{array}$ & $\begin{array}{l}\text { Waste flour with } \\
\text { cow dung }\end{array}$ & Cumulative amount of gas \\
\hline Day 1 & & 0.2 & \\
\hline Day 2 & & 0.4 & \\
\hline Day 3 & & 0.3 & \\
\hline Day 4 & & 0.4 & \\
\hline Day 5 & 0.1 & 0.5 & 1.6 \\
\hline Day 6 & & 0.5 & \\
\hline Day 7 & & 0.6 & \\
\hline Day 8 & & 0.4 & \\
\hline Day 9 & & 0.7 & \\
\hline Day 10 & 0.4 & 0.8 & 4.6 \\
\hline Day 11 & & 1.0 & \\
\hline Day 12 & & 0.9 & \\
\hline Day 13 & 0.6 & 1.2 & 7.7 \\
\hline Day 14 & & Gas Released & \\
\hline Day 15 & & 1.0 & \\
\hline Day 16 & & 1.5 & \\
\hline Day 17 & & 1.5 & \\
\hline Day 18 & & 1.4 & \\
\hline Day 19 & 1.2 & 1.6 & 14.7 \\
\hline Day 20 & & Gas Released & \\
\hline Day 21 & & 1.4 & \\
\hline Day 22 & & 1.7 & \\
\hline Day 23 & & 1.7 & \\
\hline Day 24 & & 1.8 & \\
\hline Day 25 & & 1.0 & \\
\hline Day 26 & 1.7 & 0.4 & 21.1 \\
\hline Day 27 & & Gas Released & \\
\hline Day 28 & 2.0 & 0.2 & 21.3 \\
\hline
\end{tabular}

Quantity of biogas produced daily when 10 liter slurry is decomposed waste flour with cultured bacteria
Table 2 states the daily production of biogas and their cumulative quantity from wasted flour with cultured bacterial colony (waste sample-3) within 28 days. 
It has been shown from table 2 that the production of biogas followed an increase trend with time period, when wasted flour with cultured bacterial colony slurry (waste sample-3) was used as waste material. The biogas production was $2.1 \mathrm{~L}$ during at day 5 and it was gradually increased until day 28 and produced $29.9 \mathrm{~L}$ biogas at the end of the experiment. The vessel used to reserve the biogas, has a capacity of 8 litters only. So before produce 8 litters gas in the jar, the gas was released in the air and was tried to burn.

Table 2. Biogas produced daily when 10 liter slurry is decomposed from waste flour with cultured bacteria

\begin{tabular}{|c|c|c|}
\hline \multirow{2}{*}{ Day } & \multicolumn{2}{|c|}{ Daily volume of gas produced from waste flour with cultured Bacteria (L) } \\
\hline & waste flour with cultured Bacteria & Cumulative amount of gas \\
\hline Day 1 & 0.1 & \\
\hline Day 2 & 0.3 & \\
\hline Day 3 & 0.4 & \\
\hline Day 4 & 0.6 & \\
\hline Day 5 & 0.7 & 2.1 \\
\hline Day 6 & 0.9 & \\
\hline Day 7 & 1.1 & \\
\hline Day 8 & 1.4 & \\
\hline Day 9 & 1.9 & \\
\hline Day 10 & Gas Released & 7.4 \\
\hline Day 11 & 1.9 & \\
\hline Day 12 & 2.0 & \\
\hline Day 13 & 2.0 & 13.3 \\
\hline Day 14 & 2.1 & \\
\hline Day 15 & Gas Released & \\
\hline Day 16 & 2.4 & \\
\hline Day 17 & 2.0 & \\
\hline Day 18 & 2.1 & \\
\hline Day 19 & Gas Released & 21.1 \\
\hline Day 20 & 1.8 & \\
\hline Day 21 & 1.4 & \\
\hline Day 22 & 1.0 & \\
\hline Day 23 & 1.0 & \\
\hline Day 24 & 1.1 & \\
\hline Day 25 & 0.8 & \\
\hline Day 26 & 0.4 & 29.4 \\
\hline Day 27 & 0.2 & \\
\hline Day 28 & 0.3 & 29.9 \\
\hline
\end{tabular}

According to above experiment, a comparison among the gas production rate of cow dung, waste flour with cow dung, and wasted flour with cultured bacteria were shown in Fig. 2.

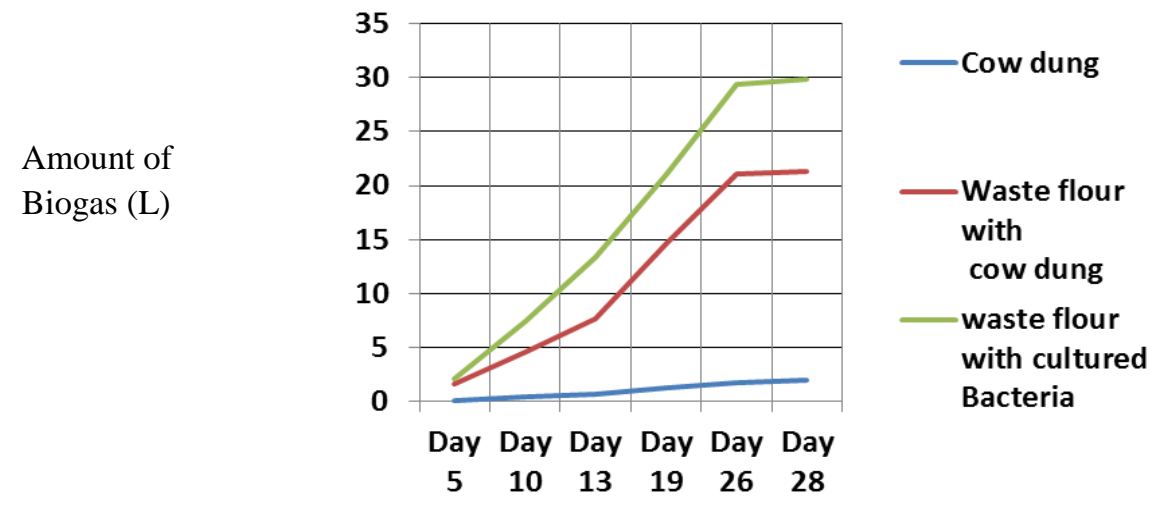

Fig. 2. Variation production of Biogas from cow dung, waste flour with cow dung and waste flour with cultured Bacteria in 28 days

Here, blue, red and green curve refer the gas production rate of cow dung, wasted flour with dung and same wasted flour with cultured bacteria respectively. After 28 days ( 4 weeks) here it is noticed that about $2.0 \mathrm{~L}$ gas was produced from cow dung where at the same time 21.3 L and 29.9 L was produced from flour-dung, and flour-bacteria respectively. 


\section{Conclusions}

The main purpose of this research was to produce more amount of biogas and to reduce the volume of garbage. Biogas technology, as it uses animal and agricultural wastes and returns the waste as fertilizer, energy being the bonus, is considered as a most appropriate technology to a developing country like Bangladesh which is mainly an agricultural based country. This research was started from January 1, 2014 and was completed at June, 12, 2014, and was held in the campus-area of Mawlana Bhasani Science and Technology University. In this experiment garbage is decomposed with only approximately all type of anaerobic bacteria. If

\section{References}

Ali, A. M. S. 1995. Population pressure, Environmental Constraints and Agricultural change in Bangladesh: Examples from Three Agro-Ecosystems. Agriculture, Ecosystems, and Environment, 55: 95109.

Gareth, M.; Evans, Judith, C., and Furlong. 2003. Environmental Biotechnology Theory and Application, $3^{\text {rd }}$ edition, Gareth M. Evans, Judith C. Furlong, pp. 190-199.

Kabir, M. H. and Mahmud, M. S. 2009. Environmental Education in Bangladesh: Institutional practices and opportunities. Development Compilation, 2(1): 1-5.

Rahman, M. H. 1996. Biogas: environmental aspects and potential for generation in Bangladesh, Int. J. Env. Educ. \& Inf., UK. R.C. Dubey 2005, A textbook of Biotechnology, 5th edition, s. chand \& company Ltd, pp. 559-563. methanogens, facultative anaerobes and other bacteria which are responsible for anaerobic digestion and biogas formation, are separately cultured, and these garbage's are separately decomposed with this bacteria, then this experiment will be resulted in more accuracy in investigation and increase the production of biogas and decrease time consuming in digestion process. However, there are some social and economic aspects, which have strong bearing on the spread of use of this technology. But if we can mitigate the problems by using low cost technology and produce biogas for our daily using purpose then it will be very much acceptable for us by environmentally, economically and reduce pollution.

United Nations Development programme (UNDP). 1995. UNDP's 1995 Report on Human Development in Bangladesh: Environment. UNDP: Dhaka, Bangladesh.

Monique, H., Kenneth, M., Noll and Ralph, S. 1986. Improved Isolation of Methanogens and other Anaerobes in a Defined Gas Atmosphere, International Journal of Applied and Environmental Microbiology, 51: 5. 